\title{
RELEASE OF SERRATIA ENTOMOPHILA FROM PRILL FORMULATIONS IS AFFECTED BY SOIL MOISTURE
}

\author{
M. O'CALLAGHAN, E.M. GERARD, V.W. JOHNSON, R.J. TOWNSEND \\ and T.A. JACKSON
}

\author{
Biocontrol and Biosecurity Group, AgResearch, PO Box 60, Lincoln \\ maureen.ocallaghan@agresearch.co.nz
}

ABSTRACT
The bacterium Serratia entomophila has been incorporated into prill
formulations to improve distribution and application of this insect pathogen
to pasture for biological control of the New Zealand grass grub, Costelytra
zealandica. While bacteria can survive in ambient conditions for long periods
within the prills, their field efficacy depends on successful release of bacteria
from the prills and colonisation of the surrounding soil. Laboratory
experiments were conducted to determine the effects of soil moisture on rate
of release of bacteria from prill formulations. Prills were held in soil adjusted
to four soil moisture contents (ranging from field capacity to wilting point),
and the release of bacteria was determined by dilution plating. Bacteria were
released most rapidly at high soil moistures, and populations were maintained
at $10^{3}-10^{4}$ colony forming units per g soil in most treatments. Measurement
of release of S. entomophila from prills in soil cores subjected to various
watering regimes demonstrated that free soil water is important for distributing
bacterial inoculum throughout soil profile.
Keywords: Serratia entomophila, biopesticide, formulation, soil Keywords: Serratia ent
inoculation, soil moisture.

\section{INTRODUCTION}

The New Zealand grass grub (Costelytra zealandica (White)) (Coleoptera: Scarabaeidae) is an important pest of pasture in New Zealand, causing pasture deterioration by feeding on the roots of grasses and clovers. The bacterial pathogen Serratia entomophila, which causes amber disease of New Zealand grass grub, has been developed as a commercial biological control agent (Invade $\AA$ ) for grass grub control, and has been applied to pastures as liquid drenches for many years (Jackson et al. 1992). The need to store the bacterial suspension product under refrigeration and the large volume of water required to apply the suspensions have posed severe constraints on the use of the product. To overcome these limitations, new formulations with more favourable storage, distribution and application properties have been developed. Johnson et al. (2001) reported the development of a claybased solid formulation of S. entomophila which met product requirements with respect to shelf-life at ambient temperatures and application conditions.

Use of Invade $\AA$ requires the delivery to soil of live bacteria that are capable of establishing in soil and maintaining viability for long enough to allow infection of grass grub larvae, thereby initiating a cycle of disease in the insect population. In a previous laboratory study, we have shown that formulation of S. entomophila maintained the bacterial population above the required level to cause disease in a grass grub population for more than four months under conditions that caused rapid loss of unformulated inoculum (O'Callaghan et al. 2001). In those experiments, prills remained relatively intact in soil, and estimates of bacterial numbers per gram of soil included bacteria still contained within the prills in addition to those released into soil.

In addition to promoting survival of microbial inoculum, an important factor determining the success of a biopesticide is the release of inoculum from the formulation and its subsequent availability to the target pest. The rate of release of inoculum is likely to be affected by soil 
conditions, especially soil moisture. In the current study, methods for the efficient extraction of bacterial cells from prills and soil were evaluated and experiments were undertaken to examine release of $S$. entomophila from prills at different levels of soil moisture and in response to varied frequency of watering. As part of this study, fluorescence microscopy was evaluated for determining inoculum release rates as an alternative to the more laborious technique of soil dilution plating.

\section{MATERIALS AND METHODS}

\section{Growth and formulation of Serratia entomophila}

Serratia entomophila strain 626 was originally isolated from pasture soil in Canterbury and is pathogenic to the New Zealand grass grub. This strain is held in the Microbial Control/ Insect Pathogen Culture Collection, AgResearch, Lincoln. Serratia entomophila was cultured by inoculating $100 \mathrm{ml}$ of broth ( $4 \mathrm{~g}$ raw sugar, $1 \mathrm{~g}$ yeast extract, $0.2 \mathrm{~g}$ urea and $0.2 \mathrm{~g} \mathrm{NPK}$ ) with $1 \mathrm{ml}$ of an overnight culture and incubating with shaking $(180 \mathrm{rpm})$ at $30^{\circ} \mathrm{C}$ for $48 \mathrm{~h}$. Cell counts were determined by serial dilution plating on Luria Bertani (LB) agar (Sambrook et al. 1989).

Serratia entomophila was formulated into prills using methods developed at AgResearch, Lincoln, for the stabilisation of non-sporeforming bacteria (NZ Patent 50687). Briefly, broth cultures were concentrated by centrifugation and then incorporated in a biopolymer matrix. Extruded clay-based prills were 1-3 mm in size with a moisture content of 35-40\%. Bacterial loading on the prills was estimated by dilution plating on LB agar.

\section{Fluorescent labelling and visualisation of cells}

Cells from an overnight culture of S. entomophila 626 were concentrated by centrifugation, rinsed and suspended overnight at $4^{\circ} \mathrm{C}$ in phosphate buffer (PB) containing $1 \mathrm{mg} / \mathrm{ml}$ fluorescein isothiocyanate (FITC, Sigma Chemical). Cells were rinsed by multiple centrifugation cycles in PB. Soil extracts were examined for the presence of fluorescent cells using an Olympus BH100 microscope with epifluorescent attachments. Quantitative recovery of formulated $S$. entomophila from prills and soil

Preliminary experiments indicated that in some formulations bacteria were tightly bound and difficult to extract from soil, leading to underestimation of the numbers of bacteria present in soil after application (E.M. Gerard, unpubl. data). To overcome this problem, the efficiency of the extraction process was determined for two formulations (Experiment 1: formulation T126; Experiment 2: formulation T164). The release of cells from prills was compared using two diluents: one was a standard laboratory diluent, phosphate buffer $(0.1 \mathrm{M})$, while the other was a $0.01 \%$ solution of sodium pyrophosphate, which acts as dispersion agent (Riis et al. 1998), plus Tween 80 ( $1 \mathrm{ml} /$ litre). Prills (1 g) were added to $9 \mathrm{ml}$ diluent and shaken for $1 \mathrm{~min}$ before preparation of a dilution series for bacterial enumeration. Four replicates were prepared for each diluent treatment of each formulation.

To test efficiency of recovery of formulated S. entomophila cells from soil (Experiment 3 ), prills ( $0.5 \mathrm{~g}$ with known bacterial concentration) were added to plastic bags containing approximately $1500 \mathrm{~g}$ field-collected soil. Soil was mixed and $200 \mathrm{~g}$ sub-samples were used to prepare soil suspensions by addition of $1800 \mathrm{ml}$ diluent to each sample. Tap water, which was usually used in preparation of soil dilutions, was compared with sodium pyrophosphate/Tween solution. Soil suspensions were left standing for $1 \mathrm{~h}$ before a dilution series was prepared for bacterial enumeration. Two formulations were used in the efficiency trials (T126 and T164) and four replicates were prepared for each diluent treatment.

Serratia entomophila populations in soil were enumerated by soil dilution plating onto a selective medium, caprylate thallous agar (Starr et al. 1976). After incubation for 6 days at $30^{\circ} \mathrm{C}$, the identity of each colony was verified as described previously (O'Callaghan \& Jackson 1993).

\section{Effect of soil moisture on release of $S$. entomophila from prills}

Field soil (Wakanui silt loam; $\mathrm{pH}=6.3$, organic matter 5.4\%) was collected at Lincoln, Canterbury. The soil was sieved and stored at $4^{\circ} \mathrm{C}$ until used. Soil moisture content was determined by drying $20 \mathrm{~g}$ soil at $60^{\circ} \mathrm{C}$ for $24 \mathrm{~h}$. Samples of the soil were either air-dried or moistened with tap water to give the required soil moisture contents of $15 \%$ (equates to wilting point), $20 \%, 25 \%$ and $30 \%$ (w/w) (equates to field capacity). The equivalent of $50 \mathrm{~g}$ 
dry soil was added to $30 \mathrm{ml}$ sterile plastic tubes. Bags $(3 \times 3 \mathrm{~cm})$ were prepared from nylon (mesh size $0.5 \mathrm{~mm})$. Prills were weighed into the bags $(0.2 \mathrm{~g}$ of $\mathrm{T} 214$ which contained $5 \times 10^{9} \mathrm{cfu} / \mathrm{g}$ prills). The bags were buried in soil microcosms to give a rate of approximately $10^{7} \mathrm{cfu} / \mathrm{g}$ air dried soil. The microcosms were incubated in a constant temperature cabinet $\left(15 \pm 1{ }^{\circ} \mathrm{C}\right)$. At each sampling date, three replicate tubes were randomly selected and destructively sampled. Prills were removed from bags and bacteria enumerated by dilution plating onto CTA. Bacteria that had been released into soil were enumerated by dilution plating a subsample of soil from the tube onto CTA.

Effect of watering regime on release of $S$. entomophila from prills

Field soil was collected and prepared as described above. Soil (1600 g) with an initial water content of $20 \%$ was placed in free draining tubes $(10 \mathrm{~cm}$ diameter x $25 \mathrm{~cm}$ height). Prills $(1 \mathrm{~g})$ containing fluorescent labelled cells were placed on the surface of the soil in the centre of the core, and covered with $200 \mathrm{~g}$ soil. The prills contained $5.6 \times 10^{9} \mathrm{cfu} / \mathrm{g}$, a rate of approximately $5 \times 10^{6} \mathrm{cfu} / \mathrm{g}$ soil. Cores were held in a constant temperature room $\left(15 \pm 1^{\circ} \mathrm{C}\right)$ and removed for watering under a precision horticultural sprayer. Water was applied in fine mists equivalent to $12.5 \mathrm{~mm}$ over $2 \mathrm{~h}$ at intervals of 1,3 or 7 days, with an unwatered treatment as a control. The watering regime was maintained for 21 days and pots were then left for a further 7 days before destructive sampling took place. Intact soil cores were cut into three sections $(0-8 \mathrm{~cm}, 8-16 \mathrm{~cm}$ and $16-24 \mathrm{~cm})$. These sections were separated and stored for subsequent soil dilution and enumeration of bacteria, as described above. At the time the cores were dismantled, soil around the position of the prills was carefully excavated and the condition of the prills observed. Small sub-samples of soil (approximately $0.1 \mathrm{~g}$ ) were also taken from immediately adjacent to the prills for fluorescence microscopy.

Statistical analyses

Numbers of colony forming units ( $\mathrm{cfu}) / \mathrm{g}$ soil were $\log _{10}$ transformed before data were analysed using analysis of variance (Genstat).

\section{RESULTS}

Efficiency of recovery of $S$. entomophila from formulations

Efficiency of recovery of $S$. entomophila cells from prills varied between different batches of prills and diluent used (Table 1). Where prills were suspended in buffer before dilution plating (Experiments 1 and 2), there was a visual difference in the dispersal rate, with prills remaining intact in PB but breaking apart in sodium pyrophosphate solution. This observation was supported by the improved recovery rate of bacteria from prills where sodium pyrophosphate was used, although the difference was not always statistically significant owing to high variability in the counts.

TABLE 1: Mean percentage recovery of $S$. entomophila cells from prills (Experiments 1 and 2) and from prills applied to soil (Experiment 3).

\begin{tabular}{lcccc}
\hline & $\begin{array}{c}\text { Experiment 1 } \\
\text { Formulation }\end{array}$ & T126 & Experiment & \multicolumn{2}{c}{ Experiment 3 } \\
& $1.2 \times 10^{9}$ & $9.9 \times 10^{9}$ & $5.45 \times 10^{5}$ & $5.63 \times 10^{6}$ \\
Initial count $^{1}$ & & & & \\
Treatments & 60 & 12 & 84 & 67 \\
$\begin{array}{l}\text { Phosphate buffer } \\
\text { Tap water }\end{array}$ & 92 & 54 & 115 & 88 \\
Na pyrophosphate & 38 & 11 & 49 & 22 \\
LSD (P<0.05) & $\mathrm{P}<0.10$ & $\mathrm{P}<0.001$ & $\mathrm{P}>0.05$ & $\mathrm{P}>0.05$ \\
Significance & & & & \\
\end{tabular}

${ }^{1}$ For Experiments 1 and 2, count is colony forming units/g granule; for Experiment 3, count is colony forming units/g oven dry soil. 
Release of $S$. entomophila from prills placed in soil at various moisture contents Soil around the bags of prills was rapidly colonised by bacteria, with different $(\mathrm{P}<0.05)$ bacterial populations established according to moisture condition within 7 days of application (Fig. 1). The greatest number of bacteria were released from prills under conditions of high soil moisture (30\% = field capacity) resulting in bacterial populations of approximately $10^{4} \mathrm{cfu} / \mathrm{g}$ soil throughout the experiment. Establishment rate was slower at the lower soil moisture contents but all treatments approximated $10^{4} \mathrm{cfu} / \mathrm{g}$ soil by 58 days from application and were maintained within a factor of ten of this until the end of the experiment (113 days). Inoculum was rapidly leached from the prills in the soils at field capacity (Fig. 2) but a larger proportion of inoculum remained within the

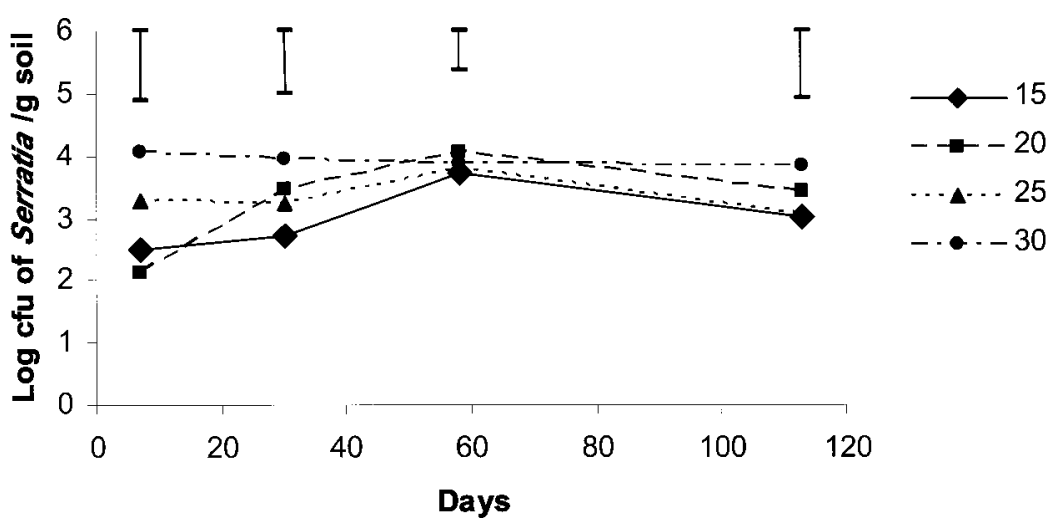

FIGURE 1: Mean numbers $\left(\log _{10}\right)$ of Serratia entomophila colony forming units/g oven dry soil in soils held at soil moisture contents of 15, 20, 25 or $30 \%(w / w)$ for different periods following inoculation of soil with prills containing the bacterium. Error bars are LSD $(\mathbf{P}<0.05)$.

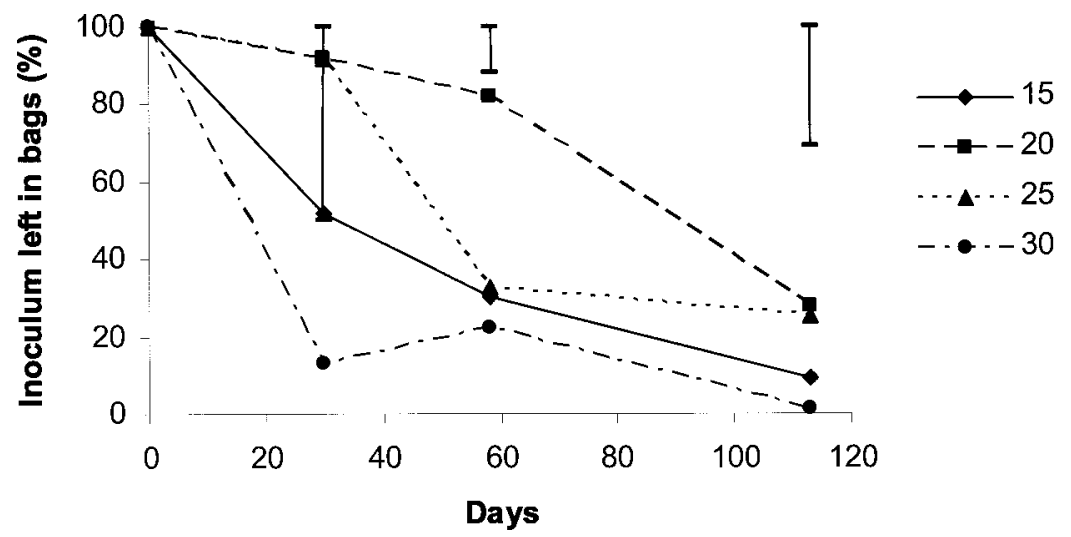

FIGURE 2: Mean percentage of initial inoculum remaining in bags after inoculation of soil with prills containing Serratia entomophila and holding the soils at moisture contents of $15,20,25$ or $30 \%(w / w)$ for different periods. Error bars are LSD $(\mathbf{P}<\mathbf{0 . 0 5})$. 
prills at the intermediate soil moisture contents. Percentage of initial inoculum remaining in the prills at the end of the experiment was lowest in the soils held at the high moisture content (9\% inoculum remaining) and the low moisture content (1\% remaining)(Fig. 2). Effect of watering regime on release of $S$. entomophila from prills

Intact prills could be seen in cores that remained unwatered throughout the trial. Soil in the top section of the cores where the prills were applied had soil moisture of $17 \%$ at the termination of the experiment (after 4 weeks), and the intact prills could be easily separated from surrounding soil. In all of the other treatments, only remnants of the prills (clay residues) could be detected in soil. In soil cores that remained unwatered, there was no movement of $S$. entomophila away from prills to soil lower in the profile (Table 2). Over $10^{6} \mathrm{~S}$. entomophila/g soil were recovered from the top layer of soil, which was approximately $40 \%$ of initial amount applied. Lower numbers of bacteria were recovered from the top layers of cores which had been watered, but in all cases, numbers remained above $10^{4} \mathrm{cfu} / \mathrm{g}$ soil. Numbers of bacteria in the two lower sections of the soil cores increased $(\mathrm{P}<0.05)$ with increasing water contents.

TABLE 2: Mean $\log _{10}$ numbers of Serratia entomophila colony forming units/g soil (and percentage soil moisture contents in brackets) at three depths in experimental soil cores.

\begin{tabular}{|c|c|c|c|}
\hline Treatment & $0-8 \mathrm{~cm}$ & $\begin{array}{c}\text { Depth in soil } \\
8-16 \mathrm{~cm}\end{array}$ & $16-24 \mathrm{~cm}$ \\
\hline Unwatered & $6.35(17 \%)$ & $-\quad(28 \%)$ & $-\quad(30 \%)$ \\
\hline Watered weekly & $5.03(33 \%)$ & $2.54(31 \%)$ & $2.57(34 \%)$ \\
\hline Watered every 3 days & $4.59(34 \%)$ & $4.15(30 \%)$ & $3.14(32 \%)$ \\
\hline Watered daily & $5.26(36 \%)$ & $4.19(29 \%)$ & $3.84(31 \%)$ \\
\hline LSD $(\mathrm{P}<0.05)$ & 0.385 & 0.628 & 0.710 \\
\hline
\end{tabular}

\section{Fluorescence microscopy}

Estimation of release rate of bacteria from prills, using fluorescence microscopy, proved difficult because of insufficient contrast between fluorescence of the labelled cells and natural background fluorescence of organisms and inert matter in the soil. Despite these difficulties, qualitative assessments could be made confirming that fluorescing cells corresponding to $S$. entomophila were more abundant in soil taken from around the watered prills than in the unwatered prills. The technique was not sufficiently sensitive to positively detect cells from the lower soil depths.

\section{DISCUSSION}

High levels of efficient and consistent recovery of formulated micro-organisms from soil are important for accurate evaluation of establishment and field persistence of biocontrol agents. In the present study, the efficiency of extraction of formulated S. entomophila was increased by preparing soil suspensions in pyrophosphate rather than in water or phosphate buffer. This is consistent with other studies using pyrophosphate in recovery of bacteria from soil (e.g. Lindahl 1996), and the technique should be regularly used in studies for evaluation of soil microbial populations.

The target level of establishment of $S$. entomophila to initiate a cycle of amber disease in the grass grub population is $10^{4} \mathrm{cfu} / \mathrm{g}$ soil (O'Callaghan et al. 1999). When applied as a liquid, numbers of bacteria decline by approximately a factor of 10 per month. Application of bacteria in prills results in highly concentrated foci of bacteria which must be released into the surrounding soil in order to cause infection in grass grub populations. When prills were established in soils at different moisture levels, bacteria 
were released most rapidly into the wettest soils where bacterial populations of up to $10^{4} \mathrm{~S}$. entomophila/g soil were recovered from soil at field capacity after 1 week. Equivalent bacterial establishment in the soil took up to 2 months at lower soil moistures. The delayed establishment may have been influenced by experimental conditions. The use of nylon bags to contain the prills may have impaired water uptake by the prills, while the absence of soil invertebrates in the experimental system may also have reduced the rate at which the prills disintegrated in soil. However, the extended persistence of the bacteria and their prolonged release from the prills was promising, as previous studies have shown that numbers of bacteria from unformulated $S$. entomophila decline at a steady rate of a factor of ten per month following application (O'Callaghan et al. 2001).

Movement of bacterial inoculum away from the point of inoculation will be an important factor in the success of a biocontrol agent applied to soil, especially when the target pest is not very mobile in soil. The role of percolating water is considered important in distributing micro-organisms through soil (Hekman et al. 1995). The experiment examining the effect of watering regime on bacterial movement through the soil profile confirms the importance of free water for bacterial distribution. Movement of bacteria to the lower parts of soil profiles is indicative of bacterial release from the prills. The rate of movement to the lower depths in the profile was dependent on the frequency of watering, with no movement recorded in the unwatered treatment. In cores subjected to daily watering, substantial bacterial populations were still maintained in the upper soil profiles, which is important as it is necessary to maintain maximum numbers of bacteria in this zone where grass grub larvae will be feeding on plant roots. Use of the fluorescence microscopy technique provided supportive evidence on the distribution of bacteria but will need further development before it can be used to replace traditional plating techniques for enumeration of bacterial populations.

The experiments indicate that prill formulations can be used to effectively deliver S. entomophila bacteria to soil. The rate of release from the prills will be dependent on soil moisture and influenced by the frequency of watering, either through rainfall or irrigation. As release of bacteria from prills is delayed in dry soil conditions, early application of prills to dryland pastures is warranted. The gradual release of bacteria from the formulations appears to provide an extended period of high bacterial numbers in comparison to traditional application in liquid suspensions.

\section{ACKNOWLEDGEMENTS}

We are grateful to Jayanthi Swaminathan and Charlie Dillimore for preparation of bacterial inoculum; Sohail Qureshi for assistance with the pot trial; and Dave Saville, AgResearch Lincoln, who carried out statistical analyses and gave helpful comments on the manuscript.

\section{REFERENCES}

Hekman, W.E.; Heijnen, C.E.; Burgers, S.L.G.E.; van Veen, J.A.; van Elsas, J.D. 1995: Transport of bacterial inoculants through intact cores of two different soils as affected by water percolation and the presence of wheat plants. FEMS Microbiol. Ecol. 16: 143-158.

Jackson, T.A.; Pearson, J.F.; O'Callaghan, M.; Mahanty, H.K.; Willocks, M. 1992: Pathogen to product - development of Serratia entomophila (Enterobacteriaceae) as a commercial biological control agent for the New Zealand grass grub (Costelytra zealandica). In: Jackson, T.A.; Glare T.R. ed. Use of Pathogens in Scarab Pest Management. Intercept, Andover, UK. Pp. 191-198.

Johnson, V.W.; Pearson, J.F.; Jackson, T.A. 2001: Formulation of Serratia entomophila for biological control of grass grub. N.Z. Plant Prot. 54: 125-127.

Lindahl, V. 1996: Improved soil dispersion procedures for total bacterial counts, extraction of indigenous bacteria and cell survival. J. Microbiol. Methods 25: 279286. 
O’Callaghan, M.; Jackson, T.A. 1993: Isolation and enumeration of Serratia entomophila - a bacterial pathogen of the New Zealand grass grub, Costelytra zealandica. J. Appl. Bacteriol. 75: 307-314.

O'Callaghan, M.; Young, S.A.; Barlow; N.B.; Jackson, T.A. 1999: The ecology of grass grub pathogenic Serratia spp. in New Zealand pastures. Proc. $7^{\text {th }}$ Australasian Conf. Grassland Invert. Ecol.: 85-91.

O'Callaghan, M.; Gerard, E.M.; Johnson, V.W. 2001: Effect of soil moisture and temperature on survival of microbial control agents. N.Z. Plant Prot. 54: 128-135.

Riis, V.; Lorbeer, H.; Babel, W. 1998: Extraction of micro-organisms from soil: evaluation of the efficiency by counting methods and activity measurements. Soil Biol. Biochem. 30: 1573-1581.

Sambrook, J.; Fritsch, E.F.; Maniatis, T. 1989: Molecular Cloning, $2^{\text {nd }}$ ed. Cold Spring Harbour Laboratory Press, Cold Spring Harbour, N.Y.

Starr, M.P.; Grimont, P.A.D.; Grimont, F.; Starr, P.B. 1976: Caprylate thallous agar medium for selectively isolating Serratia and its utility in the clinical laboratory. $J$. Clin. Microbiol. 4: 270-276. 